\title{
Al-Madãris
}

VOL. 2, NO. 1, 2021

E-ISSN: 2745-9950

https://journal.staijamitar.ac.id/index.php/almadaris

\section{COVID-19 DALAM KAJIAN QAWAID FIQHIYAH}

\author{
Nainunis \\ Institut Agama Islam Al-Aziziyah Samalanga \\ nainunis82@gmail.com
}

\begin{abstract}
This study tries to assess the level of danger of covid-19 in the study of qawaid fiqhiyah. So that the level of vigilance is found based on the study of fiqh. There are several fiqhiyah principles that serve as basic guidelines in fostering human behavior in dealing with COVID-19, there are also some changes in the basic provisions (hukum ashal) to new provisions, which changes according to the level of the virus. The fiqhiyah rules that are relevant to this study are; 1) الشيقة تحلب النسير (difficulty can bring fast), which this rule describes the difficulties obtained from the process of spreading COVID-19 can abort obligations and change the basic provisions. 2) الضرورة تيح الغظورات (the condition of the dharurat allows something that is forbidden), from the other side this rule also describes the same thing as the rule above, where dharurah is an excuse to fail an obligation and may do things that were originally prohibited. 3) ما أييح للضرورة يقدر بقدرها (Something What is Allowed because dharurah is Measured According to the Level of 'Endanger'), this rule describes the level of permissibility or legal relief that arises due to the spread of COVID-19 not absolutely, but it is adjusted to the level of the spread zone. 4), يزال الضرر ('Endanger' must be eliminated), in the spread of COVID-19, this rule becomes the basic guide for the new obligations, namely eliminating harm caused by the spread of COVID-19 by following health protocols. 5) الهة قد نزلت منز لة الضروة عامة كانت أو خاصة (hajah;pretention Occasionally Occupies Emergency Positions either General or Special), this rule describes the desire with special criteria parallel to dharurah independently, such as hajah means, isolation of dharurah as a washilah to keep other people from being exposed.
\end{abstract}

Keywords: Covid-19, Islamic Law.

$\overline{\text { Al-Madãris, Volume 2 (1), } 2021}$ 


\section{A. Pendahuluan}

COVID-19 merupakan virus corona baru dengan kondisi atau karakter baru dan berakibat fatal pada keselamatan jiwa atau kematian manusia. Seluruh negara-negara di dunia saat ini disibukkan dengan berbagai upaya dalam pengobatan, pencegahan penularan, dan penangan dari dampak pandemi tersebut. Dampak yang ditimbulkan pandemi COVID-19 sangat luas dan multi dimensi, sehingga memaksa semua negara menetapkan kebijakan khusus untuk menanggulanginya. Tidak sedikit negara-negara dunia menjadi gamang dalam membuat keputusan dan terus berupaya menemukan cara baru yang lebih efektif dalam penanggulangan COVID-19.

Pandemi ini akhirnya mempengaruhi cara pandang dan strategi keagamaan Islam untuk mengatur bagaimana umat Islam menjalankan ibadahnya di masjid. Ini juga memaksa para ulama hadir untuk memberikan pencerahan kepada umat Islam tentang berfiqih di masa pandemi secara komprehensif agar umat Islam menjalankan berbagai ibadah wajib dan sunnah di masa wabah sebagai "new normal", keadaan normal baru yang bersifat sementara, (Farid F. Saenong, 2020: 3). Hampir di semua negara terutama yang berpenduduk muslim, para ulama melakukan ijtihad untuk menetapkan fatwa yang relevan dengan kondisi pandemi COVID-19 agar menjadi panduan di negara masing-masing seperti untuk tenaga medis, para penderita, ataupun umat Islam pada umumnya. Dalam ajaran islam, ijtihad merupakan bagian dari fiqih (tata cara dan aturanaturan dalam pelaksanaan Ibadah) yang mempunyai karakter solutif terhadap permasalahan yang muncul dan meringankan dalam aplikasi kebijakan. Untuk Itu pendekatan fiqih dapat memberikan sumbangan pemikiran dan membantu dalam pengambilan keputusan untuk mengahadapi pandemi COVID-19 yang terjadi saat ini.

Kebijakan yang dikeluarkan oleh pemerintah saat ini sejalan dengan fiqih islam. Pertimbangan paling utama dalam penetapan fatwa atau kebijakan adalah menjaga keselamatan jiwa, menjaga keberlangsungan agama melalui rukhshah, dan menjaga perekonomian. Fatwa yang dikeluarkan ulama diharapkan dapat menjadi panduan dalam beribadah, membangun kesadaran dan solidaritas umat, serta kaitannya dengan perekonomian umat. Dalam simposium tersebut Wakil Presiden juga mengajak kepada semua peserta dan pengambil kebijakan dari negara-negara muslim untuk bersatu, saling bahu membahu, membangun kerjasama dan saling tolong menolong (at-ta'awun wat-tanashur) antar sesama maupun antar negara yang membutuhkan, sehingga pandemi dapat ditangani dengan lebih baik.

Jika dikaji secara komprehensif, COVID-19 memberi dampak yang serius terhadap perilaku ummat manusia, baik dari segi hubungannya dengan Tuhan atau hubungannya dengan sesama. Dampak yang paling mendasar adalah hubungannya dengan Tuhan melalui kegiatan peribadatan sehari-hari, sehingga banyak sekali kewajiban yang tidak bisa dilakukan karena alasan keselamatan yang berimplikasi kepada rukhsah (keringanan). Menyinggung persoalan kewajiban yang tidak bisa dilakukan, maka di sini penulis akan membahas tentang penyesuaian keringanan hukum yang muncul akibat dari COVID-19

Al-Madãris, Volume 2 (1), 2021 
dengan cara menghubungkan dengan beberapa qaedah ashashiyah yang penulis rasa berkaitan. Maka dari itu tulisan ini penulis berijudul "COVID-19 Dalam Kajian Qawaid Fiqhiyah".

\section{B. Review Literatur}

Ada beberapa kajian tentang tentang COVID-19 yang sudah pernah dilakukan sebelumnya, akan tetapi bukan dalam lingkup qawaid fiqhiyah. Diantaranya:

1. penelitian yang dilakukan oleh Badri Khaeruman dkk yang berjudul Pandemi Covid-19 dan Kondisi Darurat: Kajian Hadis Tematik, Penelitian ini dilatarbelakangi oleh realita mewabahnya virus Corona (Covid-19) di akhir 2019 dan telah menjadi pandemi di seantero dunia. Penelitian ini bertujuan untuk mengungkap kebijakan Pemerintah RI mengatasi pandemi Covid-19, memunculkan petunjuk hadis dalam mengatasi pandemi Covid-19, dan mengungkap kondisi darurat bisa dibenarkan akibat pandemi Covid-19 dengan munculnya fatwa MUI. Ada beberapa hadis yang relevan sebagai petunjuk dalam mengatasi pandemi Covid-19, dan pandemi ini dapat dibenarkan sebagai kondisi darurat dengan munculnya fatwa MUI. Kebijakan jaga jarak, isolasi diri, lockdown (karantina wilayah) bukanlah metode baru di bidang epidemi penyakit. Adapun tes massal dengan mengambil sampel menjadi terobosan baru dalam mengatasi pandemi ini. Dasar hukum atas kondisi darurat adalah Alquran, Sunnah, dan Ijtihad. Berkaitan dengan fatwa MUI.

2. Sahmiar Pulungan dalam penelitiannya berjudul COVID 19 Dalam Perspektif Fiqih (Studi Kasus Trapi Covid Tentang Kebersihan). Tujuan tulisan ini adalah untuk menjawab persoalan terhadap musibah yang menimpa dunia pada umumnya, khususnya Indonesia dengan adanya pandemi covid 19. Pandangan Islam menyatakan bahwa menjaga kebersihan agar tidak terserang penyakit adalah upaya terbaik. Banyak ayat dan hadis menganjurkan agar memperhatikan kebersihan, baik secara khusus atau yang terkait langsung dengan syarat sahnya ibadah. Penelitian ini menggunakan metode kualitatif dengan pendekatan library research. Instrument penelitian ini adalah hadis, al-quran, kitab-kitab fikih. Menurut kedokteran, cara yang paling baik untuk mengobati penyakit berjangkit dan penyakit-penyakit lainnya adalah adalah dengan cara menjaga kebersihan. Menjaga kebersihan adalah suatu langkah untuk mengantisipasi diri dari terkena penyakit termasuk pandemi covid 2019. Sesungguhnya antisipasi lebih baik dari mengobati.

\section{Metodelogi}

Adapun jenis pendekatan penelitian yang digunakan dalam penelitian ini adalah penelitian kualitatif. Dan penelitian kualitatif itu sendiri masih memiliki beberapa jenis klasifikasi yang berbeda. Terdapat empat jenis penelitian dalam pendekatan kualitatif, yakni: etnografi, grounded theory, studi kasus, dan fenomenologi. Di antara empat jenis penelitian tersebut, yang menjadi fokus perhatian peneliti dalam penelitian ini adalah penelitian grounded theory. Jenis

Al-Madãris, Volume 2 (1), 2021 
penelitian grounded theory merupakan upaya menemukan teori atas dasar empirik. Untuk membangun teori dalam penelitian kualitatif, peneliti berpedoman pada nalar logis dan kritis yang konsisten dengan bertitik tolak dari kejelasan masalah, efisiensi, integrasi, ruang lingkup, signifikansi, dan kontinuitas. Perlu dicatat bahwa dalam metode penelitian ini, teori tidak dibangun dengan pendekatan berpikir deduktif. (Noeng Muhadjir, 2012:87)

Pendekatan yang dilakukan adalah deskriptif yang berupa deskripsi katakata. Moleong mengungkapkan sebelas karakteristik penelitian kualitatif, yaitu: berlatar alamiah, manusia sebagai alat (instrumen), menggunakan metode kualitatif, analisa data secara induktif, teori dari dasar/grounded theory (menuju pada arah penyusunan teori berdasarkan data), data bersifat deskriptif (data yang dikumpulkan berupa kata-kata, gambar dan bukan angka-angka), lebih mementingkan proses dari pada hasil, adanya batas yang ditentukan oleh fokus, adanya kriteria khusus untuk keabsahan data, dan desain yang bersifat sementara (desain penelitian terus berkembang sesuai dengan kenyataan lapangan), hasil penelitiaan dirundingkan dan disepakati bersama (hasil penelitian dirundingkan dan disepakati bersama antar peneliti dengan sumber data). (Lexy J. Moleong, 2016: 13) Dari kutipan ini dapat dipahami bahwa penulis menekankan akan pentingnya proses dalam penelitian dibandingkan hasilnya. Secara umum pendekatan penelitian kualitatif pada studi kepustakaan sama dengan penelitian kualitatif yang lain. Yang menjadi perbedaan hanyalah sumber data atau informasi yang dijadikan sebagai bahan penelitian

\section{Hasil Kajian}

1. Tinjauan Umum Tentang COVID-19

Infeksi virus Corona disebut COVID-19 (Corona Virus Disease 2019) kumpulan virus yang bisa menginfeksi sistem pernafasan. Pada banyak kasus, virus ini hanya menyebabkan infeksi pernapasan ringan, seperti flu, namun virus ini juga bisa menyebabkan infeksi pernapasan berat, seperti infeksi paru-paru (pneumonia). Virus ini pertama kali ditemukan di kota Wuhan China pada akhir Desember 2019. Virus ini menular dengan sangat cepat dan telah menyebar ke hampir semua negara, termasuk Indonesia, hanya dalam waktu beberapa bulan. Hal tersebut membuat beberapa negara menerapkan kebijakan untuk memberlakukan lockdown dalam rangka mencegah penyebaran virus Corona. Di Indonesia sendiri, diberlakukan kebijakan Pembatasan Sosial Berskala Besar (PSBB) untuk menekan penyebaran virus ini, (covidl9.go.id: akses 02-07-2020).

Dinamakan coronavirus karena permukaannya yang berbentuk seperti mahkota (crown/ corona). Virus lain yang termasuk dalam kelompok yang serupa adalah virus yang menyebabkan Middle East Respiratory Syndrome (MERS-CoV) dan Severe Acute Respiratory Syndrome (SARS-CoV) beberapa tahun silam. Namun, virus corona dari Wuhan ini merupakan virus baru yang belum pernah teridentifikasi pada manusia sebelumnya. Karena itu, virus ini juga disebut sebagai 2019 Novel Coronavirus atau 2019-nCoV. Virus corona umumnya ditemukan pada hewan seperti unta, ular, hewan ternak, kucing, dan kelelawar. Manusia dapat tertular virus apabila terdapat riwayat kontak dengan hewan tersebut, misalnya pada

$\overline{\text { Al-Madãris, Volume 2 (1), } 2021}$ 
peternak atau pedagang di pasar hewan. Namun, adanya ledakan jumlah kasus di Wuhan China menunjukkan bahwa coronavirus dapat ditularkan dari manusia ke manusia. Virus bisa ditularkan lewat droplet, yaitu partikel air yang berukuran sangat kecil dan biasanya keluar saat batuk atau bersin. Apabila droplet tersebut terhirup atau mengenai lapisan kornea mata, seseorang berisiko untuk tertular penyakit ini. Meski semua orang dapat terinfeksi virus corona, mereka yang lanjut usia, memiliki penyakit kronis, dan memiliki daya tahan tubuh rendah lebih rentan mengalami infeksi ini serta komplikasinya, (klikdokter.com: akses, 02-07-2020).

Coronavirus dapat menimbulkan gejala yang bervariasi, mulai dari flu biasa hingga gangguan pernapasan berat menyerupai pneumonia. Gejala yang umum dialami mereka yang mengalami infeksi coronavirus adalah:

a. Demam tinggi disertai menggigil

b. Batuk kering

c. Pilek

d. Hidung berair dan bersin-bersin

e. Nyeri tenggorokan

f. Sesak napas

Gejala tersebut dapat bertambah parah secara cepat dan menyebabkan gagal napas hingga kematian. Centers for Disease Control and Prevention (CDC) gejala infeksi virus tersebu dapat muncul mulai dua hari hingga 14 hari setelah terpapar virus tersebut, (klikdokter.com: akses, 02-07-2020). Ada beberapa gejala lain yang juga bisa muncul pada infeksi virus Corona meskipun lebih jarang, yaitu: a) Diare, b) Sakit kepala, c) Konjungtivitis, d) Hilangnya kemampuan mengecap rasa atau mencium bau dan e) Ruam di kulit. Gejala-gejala COVID-19 ini umumnya muncul dalam waktu 2 hari sampai 2 minggu setelah penderita terpapar virus Corona, (klikdokter.com: akses, 02-07-2020).

\section{Tahapan Penyebaran COVID-19}

Organisasi Kesehatan Dunia (WHO) dan para pakar kesehatan banyak mengulas tentang cara penularan virus corona ada dua cara:

\section{a. Penularan Langsung}

Ludah yang bermuatan virus corona bisa saja menular langsung dari satu orang ke orang lainnya, saat mereka berdekatan, misalnya si A yang sudah terpapar virus corona bicara, menguap, batuk, bersin atau meludah, lalu percikan ludah, baik disengaja atau tidak menyembur ke wajah orang lain dan tepat masuk ke mata, lubang hidup, atau mulut orang itu. Oleh air mata, ingus, dan ludah yang ketelan, virus dibawa masuk ke tenggorokan, karena ketiganya punya jalur yang saling terhubung. Maka, menularlah virus itu. Teknisnya bisa macam-macam, tapi pada prinsipnya ludah bermuatan corona berpindah secara langsung dari penderita ke mata, lubang hidung dan mulut orang lain yang sehat, di mana saja, kapan saja dan dalam situasi apa saja serba memungkinkan.

\section{b. Penularan Tidak Langsung}

Ketika ada orang bicara, menguap, batuk, bersin atau meludah, percikan ludah bermuatan virus corona akan terlempar keluar. Mungkin tidak mengenai mata, lubang hidung, atau mulut orang lain. Tapi percikan ludah bermuatan virus 
itu bisa menempel di permukaan benda padat apa saja. Bisa di baju kita, bisa di.meja, kursi, kain, kaca, dinding mobil, tangki motor, sayuran, kantong plastik dan lain-lain. Karena sifat virus corona mampu bertahan di permukaan bendabenda padat hingga hitungan jam, maka potensi penyebarannya makin sulit dilacak dan tidak terkendali. Cara menularnya sederhana. Saat kita tanpa sengaja memegang benda yang terkena percikan ludah itu di mana saja dan entah oleh siapa saja, lalu kita tanpa sadar memasukkan jari ke hidung (ngupil), ke mulut atau mengusap mata kita, pada saat bersamaan virus corona akan masuk ke tubuh kita melalui mata, lubang hidung dan mulut kita itu. Jadi dalam hal ini, jari-jari tangan kita paling potensial menjadi sarana masuknya virus corona dari permukaan benda-benda ke tubuh kita yang bersifat tidak langsung. Sampai tahap ini, mudah dipahami kalau penyebaran virus corona sangat cepat, masif dan seperti sulit dikontrol, (tagar.id: akses, 02-07-2020)

\section{Kriteria Wilayah Berdasarkan Risiko Penyebaran COVID-19}

Berikut ini penulis mengutip langsung pernyataan Gugus Tugas Nasional Percepatan Penanganan COVID-19 tentang kriteria wilayah berdasarkan risiko penyebaran COVID-19;

Penanganan COVID-19 telah merincikan empat level kriteria zonasi daerah berdasarkan warna, sebagai indikator kategori risiko COVID-19 yang dilihat dari tingkatan transmisi atau penyebarannya.

Beberapa kriteria wilayah ini mulai dari wilayah berisiko :

a. Zona Hijau (Tidak Terdampak)

b. Zona Kuning (Risiko Rendah)

c. Zona Orange (Risiko Sedang)

d. Zona Merah (Risiko Tinggi)

Berikut ini ciri-ciri daerah dengan tingkat risiko penyebaran virus corona COVID-19 mulai dari yang tertinggi hingga yang terendah.

a. Zona Merah

Pada wilayah dengan zona merah, tingkat transmisi penyeberan virus corona COVID-19 sangat cepat. Ciri cirinya adalah:

1) Terjadi transmisi lokal atau penyebaran virus corona antar warga setempat di satu wilayah dengan cepat.

2) Wabah menyebar secara luas dan banyak kluster-kluster baru di wilayah tersebut.

Pada status zona merah ini maka tiap daerah harus melakukan :

1) Melakukan pengetesan virus corona secara lebih intensif

2) Melakukan penelusuran kontak secara agresif pada kasus pasien positif, Pasien Dalam Pengawasan (PDP) maupun Orang Dalam Pemantauan (PDP).

3) Masyarakat harus tetap berada di dalam rumah

4) Perjalanan tidak diperbolehkan

5) Pertemuan publik tidak diperbolehkan dan tempat-tempat umum ditutup.

Al-Madãris, Volume 2 (1), 2021 
6) Aktivitas bisnis ditutup kecuali untuk keperluan esensial seperti farmasi, supermarket bahan pokok, klinik dan stasiun bahan bakar dengan tetap menjalankan protokol kesehatan physical distancing.

7) Prioritas penggunaan fasilitas kesehatan

8) Menutup seluruh fasilitas pendidikan

9) Melarang aktivitas berkumpul

b. Zona Oranye

Pada wilaya dengan zona oranye ini tingkat transmisi penyebaran corona COVID-19 masih tinggi.

1) Transmisi lokal munkgin bisa terjadi dengan cepat

2) Transmisi dari imported case mungkin bisa terjadi dengan cepat

3) Kluster baru harus terpantau dan dikontrol melalui testing dan racing secara agresif

Yang harus dijalankan oleh pemerintah derah dengan status oranye adalah:

1) Masyarakat disarankan tetap berada di rumah

2) Menjaga jarak di semua aspek

3) Pembatasan penumpang dan protokol kesehatan ketat di transportasi publik

4) Tempat umum ditutup

5) Fasilitas pendidikan ditutup untuk sementara

6) Masyarakat bekerja dari rumah kecuali untuk fungsi tertentu

7) Perjalanan dengan protokol kesehatan diperbolehkan.

8) Aktivitas bisnisdibuka terbatas selain untuk keperluan esensial seperti farmasi, supermaket bahan pangan pokok, klinik dan stasiun pengisian bahan bakar dengan menerapkan physical distancing.

c. Zona Kuning

Pada wilayah dengan zona kuning:

1) Kemungkinan terjadinya transmisi lokal masih cukup besar dan mungkin cepat.

2) Transmisi dari imported cases bisa terjadi cepat

3) Transmisi tingkat rumah tangga bisa terjadi

4) Kluster penyebaran terkendali dan tidak bertambah

Yang harus dijalankan oleh pemerintah daerah dengan wilayah zona kuning adalah:

1) Masyarkat dapat melakukan aktivitas di luar rumah dengan menerapkan protokol kesehatan yang ketat.

2) Penelusuran kontak secara agresif pada kasus pasien positif PDP dan ODP.

3) Menjaga jarak baik di dalam maupun di luar ruangan

4) Perjalanan dengan protokol kesehatan sangat ketat diperbolehkan.

5) Aktivitas bisnis dibuka dengan protokol kesehatan ketat.

6) Tempat olahraga dibuka dengan protokol kesehatan ketat.

7) Fasiltias layanan kesehatan dibuka secara normal

8) Kelompok rentan tetap tinggal di rumah

Al-Madãris, Volume 2 (1), 2021 
9) Kegiatan keagamaan terbatas bisa dilakukan.

d. Zona Hijau

Pada wilayah dengan status zona hijau memiliki ciri-ciri sebagai berikut:

1) Tidak ditemukan kasus positif terinfeki virus corona COVID-19

2) Penyebaran virus COVID-19 terkontrol

3) Risiko penyebaran tetap ada, di tempat-tempat isolasi

4) Pengawasan ketat dan berkala dilakukan untuk mencegah timbulnya potensi kasus baru.

Yang harus dilakukan oleh pemerintah daerah di zona hijau adalah:

1) Melakukan pemeriksaan ketat di pintu-pintu masuk wilayah

2) Tetap secara Intensif melakukan testing virus corona.

3) Pengawasan terhadap mobilitas penduduk lintas daerah

4) Penelusuran kontak agresif jika ada ODP, PDP dan OTG.

5) Memperhatikan pelaksanaan standar protokol kesehatan

6) Aktivitas bisnis dibuka normal dengan penerapan protokol kesehatan yang ketat.

7) Kegiatan keagamaan dibuka

8) Kewajiban tinggal di rumah sakit bila terjadi gejala flu, (nasional.kontan.co.id: akses, 02-07-2020).

\section{Tingkatan Antisipasi Ketika Muncul COVID-19}

\section{a. Dharuriyah}

Dharuriyat adalah tingkat kebutuhan yang harus ada atau disebut dengan kebutuhan primer. Bila tingkat kebutuhan ini tidak terpenuhi, akan terancam keselamatan umat manusia. Keperluan dan perlindungan al-dharuriyah ini dalam buku ushul fiqh, termasuk as-Sythibi, membagi menjadi lima buah, yaitu pemenuhan keperluan serta serta perlindungan yang diperlukan untuk:

1) keselamatan agama (ketaatan ibadah kepada Allah SWT)

2) keselamatan nyawa (perindividu),

3) keselamatan akal (termasuk hati nurani),

4) keselamatan atau kelangsungan keturunan (eksistensi manusia) serta terjaga dan terlidunginya harga diri dan kehormatan seorang dan

5) keselamatan serta perlindungan atas harta kekayaan yang dikuasai atau dimiliki seorang, (Al Yasa' Abubakar, 2012: 85).

Kelima dharuriyah tersebut adalah hal yang mutlak harus ada pada diri manusia. Karenanya Allah swt menyuruh manusia untuk melakukan segala upaya keberadaan dan kesempurnaannya. Sebaliknya Allah swt melarang melakukan perbuatan yang dapat menghilangkan atau mengurangi salah satu dari lima dharuriyat yang lima itu. Segala perbuatan yang dapat mewujudkan atau mengekalkan lima unsur pokok itu adalah baik, dan karenanya harus dikerjakan. Sedangkan segala perbuatan yang merusak atau mengurangi nilai lima unsur pokok itu adalah tidak baik, dan karenanya harus ditinggalkan. Semua itu mengandung kemaslahatan bagi manusia, (Amir Syarifuddin, 2008: 209). Bila salah satunya tidak ada maka hidup manusia akan terancam, berada dalam

Al-Madãris, Volume 2 (1), 2021 
kesulitan yang sangat besar dan berkepanjangan, yang akan membawanya kepada kepunahan, (Al Yasa', :85).

Mengenai masalah urutan ada ulama berpendapat bahwa urutan sesuai dengan yang disebutkan diatas, artinya perlindungan dan pemenuhan keperluan agama didahulukan atas empat yang dibawahnya dan perlindungan nyawa didahulukan atas tiga dibawahnya dan begitulah seterusnya secara berurutan. Dan ada juga ulama yang menganggap empat dari lima keperluan diatas yaitu selain agama setingkat, artinya seorang boleh memilih mana yang akan diutamakan dan mana yang akan ditinggalkan atau dikorbankan sesuai dengan pertimbangan dan keadaan nyata yang dia hadapi. Dan semua ulama sepakat bahwa perlindungan agama merupakan yang tertinggi, (Al Yasa', :87).

Dalam menghadapi penyebaran COVID-19, penulis menganalisa bahwa kondisi yang bisa digolongkan kedalam tahap dharuriyah adalah tingkat penyebaran COVID-19 di wilayah tertentu sudah dalam tahapan darurat yang disebut dengan zona merah dan oranye. Di mana pemerintah sudah menetapkan Pembatasan Sosial Berskala Besar (PSBB). Dan di sini penulis melihat bahwa jika merujuk kepada kriteria zona di atas maka jelas terlihat banyak sekali pembatasan-pembatasan yang berlakukan, seperti; harus tetap berada dan bekerja di dalam rumah, tidak diperbolehkan melakukan perjalanan, tidak diperbolehkan pertemuan publik, tempat-tempat umum ditutup, kegiatan bisinis ditutup kecuali untuk keperluan esensial dan fasilitas pendidikan juga ditutup dan juga melarang aktivitas berkumpul, dengan alasan kemungkinankemungkinan negatif yang membahayakan jiwa sangat berpotensi karena penyebaran wabah sangat luas dan cepat, dan semua pembatasan-pembatasan tersebut adalah sebuah kesulitan yang parah ahli fiqh dan ushul fiqh menyebutnya dengan istilah المشقة

\section{b) Hajiyyah}

Hajiyyat ialah kebutuhan-kebutuhan sekunder, di mana keburtuhan ini tidak sampai mengancam keselamatan jiwa, namun akan mengalami kesulitan dan kesukaran bahkan mungkin berkepanjangan, tetapi tidak sampai ketingkat menyebabkan kepunahan atau sama sekali tidak berdaya. Jadi yang membedakan dharuriyyah dengan hajiyyat adalah pengaruhnya kepada keberadaan manusia. Namun demikian, keberadaannya dibutuhkan untuk memberikan kemudahan serta menghilangkan kesukaran dan kesulitan dalam kehidupan mukallaf, (Amir,: 209).

Jika merujuk kepada kriteria zona di atas dan menghubungkan dengan konsep hajiyyah, maka menurut penulis kriteria yang cocok di sini adalah wilayah zona kuning, yang mana masyakat diperbolehkan melakukan aktivitas di luar rumah dengan menerapkan protokol kesehatan yang ketat, yaitu : dengan menjaga jarak baik di dalam maupun di luar ruangan, boleh melakukan perjalanan, boleh melakukan aktivitas bisnis dibuka, olahraga dibuka, fasiltias layanan kesehatan dibuka secara normal, kegiatan keagamaan terbatas bisa dilakukan, dengan tanda kutip mengikuti protokol kesehatan ketat.

$\overline{\text { Al-Madãris, Volume 2 (1), } 2021}$ 


\section{c) Normal}

Dari dua keadaan di atas penulis menganalisa bahwa keadaan normal adalah kedaan dimana masyarakat masih bisa beraktivitas sebagaimana biasanya dan tidak ada perobahan alam yang mengancam agama, jiwa, akal, keturunan dan hartanya sehingga bisa menghambat kegiatan masyarakat, baik berupa kegiatan spritual keagamaan maupun kegiatan sosial lainnya. Dan juga tidak ada kebutuhan-kebutuhan yang mempersulitnya.

Prof Alyasa' Abubakar dalam tulisannya Perang Melawan COVID-19: Fiqih Antisipatif menyebutkan bahwa :

perang kita sekarang secara umum, masih pada tahap perang melawan penyebaran COVID-19, belum sampai ke tingkat perang (frontal) untuk mengusir virus setelah dia masuk dan menerobos pertahanan masyarakat kita. Dengan kalimat lain, secara umum kita sekarang berada dalam tahap berusaha agar daerah kita tetap "merupakan zona hijau", tidak berubah menjadi "kuning" apalagi "merah". Walupun mesti kita akui bahwa ada beberapa pasien yang sudah tepaksa di rawat di rumah sakit. Banyak masyarakat menganggap bahwa daerahnya, masih berada di zona hijau, sehingga tidak perlu melakukan tindakan yang dianggap berlebih-lebihan. Permintaan Pemerintah untuk melakukan sosial distancing, stay at home atau work from home apalagi lock down dianggap belum perlu. Begitu juga perintah untuk menghentikan shalat berjamaah di masjid dan shalat Jumat, kelihatannya dianggap terlalu cepat dan terlalu berlebih-lebihan. Kemudahan yang diperintahkan agama itu baru boleh/wajib kita ambil kalau daerah kita sudah menjadi zona merah (dinyatakan sebagai zona merah oleh Pemerintah). Maksudnya ketika virus betul-betul sudah masuk ke daerah kita, ketika telah ada tubuh yang jatuh bergelimpangan, (alyasaabubakar.com: akses, 05-07-2020).

Sehingga di sini jelas bahwa tingkat antisipasi sangat tergantung kepeda penentuan zona oleh pemerintah melalui Tim Pakar Gugus Tugas Penanganan COVID-19, adapun zona normal, dalam hal ini penulis sebutkan dengan zona hijau masyarakat masih diwajibkan berprilaku normal dalam hubungannya dengan kegiatan keagamaan dan hubungan sosial kemasyarakatan, tidak ada rukhsah (keringanan) bagi masyarakat terhadap kegiatan peribadatannya seperti kegiatan jum'atan dan shalat berjamaah. Di lain sisi ada sebuah kewajiban baru terhadap masyarakat, yaitu tetap berjuang mempertahankan zona hijau agar tidak berubah menjadi orange bahkan merah dengan cara mengikuti protokol kesehatan, social distancing dan lain sebagainya.

\section{E. Pembahasan}

Adapun relevansi qawaid ashasiyah terhadap COVID-19 adalah sebagai berikut:

1. المشقة تجلب التيسير (kesulitan bisa mendatangkan kemudahan)

Keadaan penyebaran COVID-19 pada tahap dharuriyaah yang memunculkan sebuah المشقة (kesulitan) dalam menunaikan kewajiban 
peribadahan, seperti; shalat jum'at, dan ibadah2 lain yang terhalang karenanya, jika merujuk ke salah satu kaidah ashasiyah, yaitu; المشتة جلب النيسير (kesulitan bisa mendatangkan kemudahan), maka di sini jelas bahwa hal tersebut bisa mendatangkan kemudahan berdasarkan analisa al-Suyuthi mengenai karakteristik kesulitan (masyaqqah) secara umum yang terbagi kedalam dua pembagian pokok:

a) Masyaqqah yang tidak dapat menggugurkan kewajiban (ibadah). Misalnya: rasa lelah ketika melakukan perjalanan haji, tidak secara otomatis menggugurkan kewajiban haji.

b) Masyaqqah yang dapat menggugurkan kewajiban. Masyaqqah jenis kedua ini terbagi lagi dalam tiga tingkatan:

1) Masyaqqah yang sangat berat dan umumnya sulit ditanggung (a'la). Seperti rasa khawatir akan keselamatan jiwa, harta, keturunan, organ tubuh, dan hal-hal mendasar lainnya. Pada taraf inilah syariat memberlakukan keringanan hukum (rukhshah). Sebab, demikian tulis al-Suyuthi, pemeliharaan jiwa dan raga untuk menjalankan kewajibankewajiban syariat lebih diutamakan daripada tidak melaksanakan sama sekali. Artinya, jika umat Islam masih 'dipaksa' melaksanakan kewajiban yang sebenarnya sudah tidak mampu dikerjakan, maka akan berakibat fatal pada keselamatan jiwa maupun raganya.

2) Masyaqqah yang sangat ringan (adna). Seperti pegal-pegal, pilek, pusing, dan lain sebagainya. Pada tingkat ini, tidak ada sama sekali legitimasi syariat untuk memberi rukhshah. Sebab kemaslahatan ibadah masih lebih penting daripada menghindari mafsadah (kerusakan)yang timbul dari masyaqqah kategori ini. Artinya, timbulnya mafsadah dari hal-hal seperti ini masih sangat minim, sehingga kemaslahatan ibadah yang nyata punya nilai lebih besar harus lebih diutamakan.

3) Masyaqqah pertengahan (al-mutawassithah) yang berada pada titik interval diantara dua bagian sebelumnya. Jenis masyaqqah yang terakhir ini bisa mendapat rukhshah, jika telah mendekati kadar masyaqqah pada urusan yang tertinggi $\left(a^{\prime} l a\right)$. Dan sebaliknya apabila lebih dekat pada kategori masyaqqah yang paling ringan (adna) maka ia tidak dapat menyebabkan rukhshah, (Ahmad Djazuli, 2000: 57).

Dari dua pembagian pokok masyaqqah di atas dapat disimpulkan bahwa keadaan penyebaran COVID-19 pada tahap dharuriyah dapat dihubungkan dengan Masyaqqah yang dapat menggugurkan kewajiban pada tahap a'la (tinggi), di mana kesulitan yang diperoleh sangat nyata keberadaannya karena akibat rasa khawatir akan keselamatan jiwa jika berperilaku normal dalam beribadah dan dalam mejalin hubungan sosial. Maka atas dasar alasan masyaqqah yang dimaksud sehingga bisa mendatangkan kemudahan, contoh: Salah satu kewajiban bagi mukallaf adalah shalat jum'at, dan shalat jum'at wajib dilakukan secara berjamaah. Dengan adanya masyaqqah kekhawatiran, sehingga kewajiban shalat jum'at secara berjamaah boleh diganti dengan yang lebih aman yaitu shalat dhuhur di rumah.

Al-Madãris, Volume 2 (1), 2021 
2. الضرورة تبيح المخورات (kondisi dharurat membolehkan sesuatu yang diharamkan)

Kesimpulan yang sama juga akan diperoleh jika melihat kepada kaidah الضرورة تيح الخظورات (kondisi dharurat membolehkan sesuatu yang diharamkan), karena makna dharurah dalam kaidah tersebut sebagaimana didefinisikan oleh Al-sayuthi adalah sesuatu yang sampai pada satu batasan di mana jika tidak melakukan sesuatu yang dilarang dia akan binasa, atau hampir binasa, (Abdurraman asSuyuthi, 1983: 85)

Dikalangan ulama ushul, keadaan yang membolehkan seseorang melakukan hal yang dilarang harus memenuhi syarat syarat sebagai berikut:

a) kondisi dharurah itu mengancam jiwa atau anggota badan

b) keadaan dharurah hanya dilakukan sekedarnya dalam arti tidak melampaui batas.

c) Tidak ada jalan lain yang halal kecuali dengan melakukan hal yang dilarang, (A. Djazuli, 2010: 72).

Wahbah Az-zuhaili, dalam bukunya Konsep Darurat dalam Hukum Islam memberikan beberapa kriteria terkait dengan dharurah, yaitu:

a) Dharurah yang dimaksud harus sudah ada bukan masih ditunggu, artinya keadaan dharurat itu betul ada didalam kenyataan.

b) Orang yang terpaksa itu tidak punya pilihan lain kecuali melanggar perintah - perintah atau larangan- larangan syara', atau tidak ada cara lain yang dibenarkan untuk menghindari kemudharatan selain melanggar hukum tersebut.

c) Hendaknya dalam keadaan adanya yang diharamkan bersama yang dibolehkan itu (dalam keadaan yang biasa) alasan yang dibolehkan seseorang melakukan yang diharamkan.

d) Jangan sampai orang terpaksa itu melanggar prinsip-prinsip syara' yang pokok yaitu:

1) Memelihara hak hak orang lain.

2) Menciptakan keadilan.

3) Menunaikan amanah

4) Menghindari Kemudharatan

5) Memelihara prinsip keberagamaan serta pokok pokok kaidah islam.

e) Orang yang terpaksa itu membatasi diri pada hal hal yang dibenarkan melakukannya karna dharurat itu dalam pandangan jumhur fuqaha pada batas yang paling rendah atau kadar yang semestinya guna menghindari kemudharatan, karena membolehkan yang haram itu adalah dharurat, dan dharurat itu dinilai menurut tingkatannya.

f) Dalam keadaan dharurat obat, hendaknya yang haram itu dipakai berdasarkan resep dokter yang adil dan dipercaya, baik dalam masalah agama dan ilmunya, dan tidak ada obat selain dari yang diharamkan.

g) Harus berlalu satu hari dan satu malam bagi orang yang terpaksa dalam masalah makanan,

$\overline{\text { Al-Madãris, Volume 2 (1), } 2021}$ 
h) Jika pemimpin dalam keadaan dharurat yang merata dapat mengetahui dengan yakin akan adanya kezaliman, atau kemudharatan yang nyata, atau kesempitan yang sangat atau adanya manfaat yang merata yang diperkirakan dapat membahayan negara apabila negara tidak mengamalkan tuntutan prinsip dharurat.

i) Hendaknya sasaran pembatalan transaksi yang karena dharurat itu adalah menciptakan keadilan, atau tidak merusak prinsip keseimbangan diantara dua pihak yang bertransaksi, (Wahbah az-Zuhaili, 1999: 73-77).

Jika masuk ke dalam contoh kasus pada keadaan penyebaran COVID-19 yang sampai pada tahap dharurah (zona merah dan oranye), kita bisa menganalisa dengan melihat kepada larangan meninggalkan kewajiban, diantaranya larangan meninggalkan shalat jum'at sebagaimana dalan hadis "Siapa yang meninggalkan shalat Jumat tiga kali tanpa uzur, niscaya ia tergolong orang munafiq"(HR. al-Thabarani). Kita perlu mencermati redaksi kedua hadits tersebut terutama pada kata udzrm dapat menggariskan bahwa meninggalkan shalat Jum'at yang dimaksudkan adalah karena "tanpa uzur", (Farid F.,: 17). Ketika tidak jum'atan bukan karena adanya uzur, maka itu bukan yang dimaksud dalam hadits tersebut. Beberapa uzur yang membolehkan tidak jumatan adalah hujan lebat yang sekiranya dapat membasahi pakaiannya dan menghalanginya melakukan shalat, salju, cuaca yang sangat dingin, sakit yang menyulitkannya ikut berjamaah di masjid, kekhawatiran adanya gangguan keselamatan jiwa, kehormatan diri, dan harta bendanya jika ia ikut jumatan. COVID-19 tergolong salah satu uzur karena kekhawatiran menulari atau tertular virusnya ketika ikut jumatan yang notabene mengharuskan dilaksanakan berjamaah. Jangankan tiga kali, lebih dari itu pun jika memang kondisi merebaknya COVID-19 belum berubah ke situasi yang aman, maka tidak melaksanakan jumatan diganti dengan shalat dhuhur empat rakaat di rumah masing- masing. Ini adalah keringanan atau dispensasi (rukhshah) dalam syariat Islam jika terdapat uzur.

\section{3. ما أبيح للضرورة يقدر بقدرها (Sesuatu Yang Dibolehkan Karena Dharurah, Diukur} Sesuai Dengan Kadar Kemudharatannya)

Kemudahan yang yang dibolehkan karena dhrururah sifatnya mengikat dan tidak mutlak, seperti yang sering dicontohkan Ulama Fiqh Memakan bangkai hanyalah dibolehkan untuk menyelamatkan diri dari rasa kelaparan dan mati dan sedekar menyelamatkan diri dari kematian, tidak boleh melampaui batas dengan memakannya hingga kenyang. Apabila tidak mengancam jiwa lagi, maka batasan kebolehannya akan berakhir pula, (Abdurraman as-Suyuthi, 2006: 212). Dokter laki-laki dibolehkan melihat aurat pasien perempuan ketika merawatnya karena darurat, tapi hanya terbatas pada anggota atau bagian tubuh yang sakit saja, tidak lebih dari itu, (Abdul Aziz M. Azzam, 2005: 153).

Jika penularan COVID-19 begitu cepat maka diperlukannya langkah pencegahan dan antisipasi agar virus ini tidak semakin menyebar luas menginfeksi masyarakat. Langkah pencegahan ini juga turut mempengaruhi cara shalat berjamaah terutama shalat Jum'at yang hukumnya wajib berjamaah, bila kondisi dalam keadaan dharurah maka shalat jum'at boleh ditinggalkan dan

Al-Madãris, Volume 2 (1), 2021 
diganti dengan shalat dhuhur, dan hal yang demekian tidak mutlak, tetapi dalam kondisi tertentu di bawah level dharurah dimana masyarakat terkadang masih memungkinkan untuk melakukan shalat berjamaah sebagaimana disampaikan oleh Sekretaris Jenderal Pimpinan Pusat Dewan Masjid Indonesia (DMI) Imam Addaruqutni mengingatkan agar shalat Jumat digelar dengan protokol kesehatan pencegahan COVID-19, (kompas.com: akses, 05-07-2020). Adapun contoh yang sudah dipraktekkan adalah di Masjid Salman Institut Teknologi Bandung (ITB), misalnya, shalat wajib berjamaah dilakukan dengan menerapkan konsep social distancing atau berjarak satu meter antarshaf. Jamaah juga memberi jarak yang cukup dengan jamaah di sampingnya. Hal serupa dilakukan Muslim di Sudan. Sesuai imbauan di negara itu, jarak shaf antarjamaah harus berjauhan dengan jarak minimal 1,5 meter, (republika.co.id: akses, 05-07-2020).

Dari penjelasan di atas dan berdasarkan kaidah ما أبيح للضرورة يقدر بقدرها (Sesuatu

Yang Dibolehkan Karena Dharurah, Diukur Sesuai Dengan Kadar Kemudharatannya), dapat disimpulkan bahwa kebebasan yang muncul karena dharurah sangat dibatasi dengan batasan-batasan yang diukur dengan kondisi tertentu. adapun untuk mengenali kondisi-kondisi yang dimaksud, pemerintah menyerahkan hal tersebut kepada parah ahli yang dalam hali ini adalah gugus tugas COVID-19.

\section{4. الضر ريزال (Kemudharatan itu harus dihilangkan)}

Kaidah diatas kembali kepada tujuan untuk merealisasikan maqashid alsyariah dengan cara menolak yang mafsadah, dengan cara menghilangkan kemudaratan atau setidaknya meringankannya. Jika dikaitkan dengan COVID-19, maka sebenarnya haram bagi yang sehat menjatuhkan dirinya pada kebinasaan dengan membiarkan dirinya terbuka peluang lebar tertular oleh orang yang sudah terinfeksi virus, dan diharamkan untuk yang sudah terinfeksi atau kemungkinan besar terinfeksi menjadikan orang lain tertular virus yang dibawanya. Dan jika masjid menjadi salah satu tempat yang paling sering dijadikan tempat berkumpul dan berinteraksi oleh umat Islam; setidaknya lima kali dalam sehari, dan semakin banyak jumlah yang berkumpul saat salat Jumat, maka Fatwa MUI No. 14 Tahun 2020 tentang Penyelenggaraan Ibadah dalam Situasi terjadi Wabah Covid-19 memiliki landasan rasional dan pembenar yang sangat kuat. Dengan mengeluarkan fatwa tersebut, setidaknya para ulama telah memberikan dukungan kuat pada pemerintah untuk meminimalkan jumlah korban, meminimalkan lokasi penyebaran dengan meminimalkan kontak langsung antar warga (social distancing), (islamsantun.org: akses, 05-07-2020).

Prof. Alyasa' Abubakar dalam tulisannya yang dipublikasikan Serambi Indonesi, Jumat 17 April 2020 mengutip satu dari tujuh butir tausiah MPU Aceh, yaitu; Tenaga medis yang merawat pasien corona, yang tidak dapat memenuhi rukun dan syarat shalat secara sempurna (biasa) boleh melaksanakan shalat hormat waktu. Dan juga meringkas tiga dari sembilan poin Fatwa Nomor 14 Tahun 2020 tentang Penyelenggaraan Ibadah dalam Situasi Wabah COVID-19, yaitu;

Al-Madãris, Volume 2 (1), 2021 
a) Orang yang telah terpapar Corona, wajib menjaga dan mengisolasi diri agar tidak menularkan virus kepada orang lain. Shalat Jumat diganti dengan shalat zuhur di tempat kediaman. Dia haram melakukan ibadah sunnah yang membuka peluang terjadinya penularan, seperti ikut jamaah shalat lima waktu/ rawatib, shalat Tarawih dan Ied di masjid atau tempat umum lainnya, serta menghadiri pengajian umum dan tabligh akbar, karena kehadirannyaberpeluang menularkan virus secara massal.

b) Orang sehat yang belum diketahui terpapar COVID-19, harus memperhatikan hal-hal berikut:

1) Ketika berada di kawasan yang potensi penularannya tinggi atau sangat tinggi berdasarkan ketetapan pihak yang berwenang, maka dia boleh meninggalkan salat Jumat dan menggantikannya dengan shalat zuhur di tempat kediaman, serta meninggalkan jamaah shalat lima waktu/rawatib di masjid atau tempat umum lainnya.

2) Dalam hal berada di suatu kawasan yang potensi penularannya rendah berdasarkan ketetapan pihak yang berwenang maka dia wajib menjaga diri agar tidak terpapar virus Corona, seperti tidak kontak fisik langsung (bersalaman, berpelukan, cium tangan), membawa sajadah sendiri, dan sering membasuh tangan dengan sabun.

c) Dalam kondisi penyebaran COVID-19 tidak terkendali sehingga mengancam jiwa, umat Islam tidak boleh menyelenggarakan shalat jumat di kawasan tersebut, sampai keadaan menjadi normal kembali dan wajib menggantikannya dengan shalat zuhur di tempat masing-masing. Demikian juga tidak boleh menyelenggarakan aktifitas ibadah yang melibatkan orang banyak dan diyakini dapat menjadi media penyebaran COVID-19, seperti shalat lima waktu berjamaah, shalat Tarawih dan Ied di masjid atau tempat umum lainnya, serta menghadiri pengajian umum dan majelis taklim, (aceh.tribunnews.com: akses, 05-07-2020).

Maka di sini dapat dianalisa bahwa, dengan sebab penyebaran COVID-19 maka akan melahirkan kewajiban baru sebagaimana terurai di atas, dengan alasan pencegahan mafsadah. Pembatasan aktivitas dalam bentuk berkumpulnya massa yang banyak menjadi langkah baik dalam menghentikan penyebaran virus yang sangat cepat bermigrasinya ini dan juga merupakan hal yang paling efektif dalam pecegahan, karena aktivitas dalam bentuk perkumpulan berpotensi besar terhadap penularan COVID-19. Selain itu juga merupakan salah satu cara unutuk terhindar dari hal yang membinasakan jiwa. Adapun menjaga jiwa dari kebinasaan merupakan sebuah kewajiban. Sehingga berksimpulan bahwa mengikuti pembatasan-pembatasan sebagaimana tersebut diatas hukumnya wajib karena untuk menghilangkan kemudharatan yang bisa membinasakan jiwa, sesuai dengan kaidah الضر ريزا ل (Kemudharatan itu harus dihilangkan).

5. الحاجة قد نزلت منز لة الضرورة عامة كانت أو خاصة (Hajat Terkadang Menduduki Posisi

Darurat Baik Umum atau Khusus)

Secara parsial, definisikan al-hajah sesuatu kepentingan yang jika dipenuhi akan menghilangkan kesusahan dan kesulitan, dan jika tidak dipenuhi maka akan

$\overline{\text { Al-Madãris, Volume 2 (1), } 2021}$ 
membuat hilangnya tujuan-tujuan yang dimaksud, (Abu Ishaq Ibrahim asSyathibi, 2003: 220). Adapun definisi dari kaidah adalah; sebuah kebutuhan (hajat), baik yang bersifat umum (kolektif) atau yang khusus (individual), terkadang diposisikan sama halnya dengan dharurah, (Abdul Haq, 2005: 245). Akan tetapi tentu saja hajat yang dimaksudkan dalam kaidah ini tidak mutlak, hanya hajat dengan kriteria dan syarat khusus. Adapun syarat-syarat yang harus dipenuhi dalam penggunaan kaidah ini adalah:

a. hajat harus benar-benar nyata dan mendesak, bukan berdasarkan asumsi. Apabila hajah tersebut tidak terpenuhi maka akan menimbulkan kesulitan atau bahkan bila dibiarkan dapat menimbulkam kerusakan.

b. hajat jelas dan spesifik dimana tidak bisa digantikan suatu yang lain.

c. hajat merupakan suatu yang umum dan wajar, bukan sesuatu yang aneh dan tidak lazim;

d. hajah bukan merupakan sesuatu dilarang karena zhat-nya, akan tetapi dilarang karena sebagai suatu yang menjadi perantara bagi suatu yang dilarang karena dapat menimbulkan kerusakan.

e. Hendaknya adanya ketetapan hukum dispensasi karena hajat ditetapkan berdasarkan nas, atau ijma' amali, atau secara nyata benar-benar mendatangkan kemaslahatan, (Walid S. az-Zahir, 2010: 682).

Menurut Sadlan, hajat dalam kaidah al-hajah Manzilah al-darurah harus memenuhi syarat sebagai berikut.

a. hajah tidak sampai menganulir yang asal, yaitu darurat;cabang, hajah tidak boleh membatalkan yang pokok.

b. hajah merupakan suatu yang mendesak saat ini, bukamasa yang akan datang;

c. pemenuhan hajat tidak bertentangan dengan syara', (Salih Ghanim alSadlan, 2000: 290).

Jika dihubungkan dengan dampak dari penyebaran COVID-19, maka dapat dianalisa bahwa hajat di sini adalah bisa dicontohkan seperti seseorang yang melakukan isolasi mandiri atau karantina karena baru saja sampai dari daerah penyebaran virus, hal ini sifatnya medesak karena potensi penyebaran virus dari orang yang baru saja sampai dari daerah penyebaran virus sangat tinggi, sehingga seandainya hal ini terbiarkan maka akan dapat menimbulkam kerusakan dan ancaman bagi keselamatan.

\section{F. Kesimpulan}

Dari uraian subtansi di atas dapat disimpulkan bahwa ada beberapa kaidah fiqhiyah yang menjadi panduan dasar dalam berperilaku ketika penyebaran wabah COVID-19, juga ada beberapa perubahan hukum ashal atau ketentuan dasar kepeda ketentuan baru, yang mana perubahan-perubahan yang dimaksud sesuai dengan tingkat level penyebaran virus. Adapun kaidah fiqhiyah yang dimaksud adala; pertama المشقة تحلب التيسير (kesulitan bisa mendatangkan kemudahan), yang mana kaidah ini menggambarkan kesukaran yang diperoleh akibat penyebaran COVID-19 bisa mengugurkan kewajiban dan merobah hukum

Al-Madãris, Volume 2 (1), 2021 
ashal. Kedua الضرورة تبيح الخظورات (kondisi dharurat membolehkan sesuatu yang diharamkan), dari lain sisi kaidah ini juga mengambarkan hal yang sama dengan kaidah di atas, yang mana dharurah menjadi sebuah alasan gugur kewajiban dan boleh melakukan hal yang semulanya dilarang, dan jika dikaitkan dengan COVID-19 bisa disimpulkan bahwa hal yang semulanya dilarang (hukum ashal) menjadi boleh akibat dharurah COVID-19 . ketiga ما أبيح للضرورة يقدر بقدرها (Sesuatu Yang Dibolehkan Karena Dharurah, Diukur Sesuai Dengan Kadar Kemudharatannya), kaidah ini menggambarkan tingkat kebolehan atau keringanan hukum yang muncul akibat penyebaran COVID-19 tidak mutlak, akan tetapi disesuikan dengan level zona penyebaran. Keempat الضر ر يزا ل (kemudharatan harus dihilangkan), dalam penyebaran COVID-19, kaidah ini menjadi panduan dasar terhadap muncul kewajiban baru, yaitu menghilangkan kemudharatan yang disebabka oleh penyebaran COVID-19 dengan cara pembatasan-pembatasan yang khusu atau dengan bahasa lain disebutkan dengan mengikuti protokol kesehatan. Kelima الحاجة قد نزلت منز لة الضرورة عامة كانت أو خاصة (Hajat Terkadang Menduduki Posisi Darurat Baik Umum atau Khusus), inti dari kaidah ini adalah hajat dengan kriteria khusus sejajar dengan posisi dharurah, seperti hajah sebagai wasilah menghilangkan dharurah, maka juga dianggap dharurah, jika dikaitkan dengan COVID-19 bisa dicontohkan seperti karantina mandiri sebagai washilah menjaga orang lain dari dharurah COVID-19.

\section{BIBLIOGRAFI}

Abubakar, Al Yasa'. (2012). Metode Istishlahiah Pemanfaatan Ilmu Pengetahuan dalam Ushul Fiqh. Banda Aceh: Diandra Primamitra Media.

Abubakar, Al Yasa'. (2020). Perang Melawan Covid. Diakses 05 Juli 2020, dari http://alyasaabubakar.com/2020/04/perang-melawan-COVID-19-fiqihantisipatif/.

Al-Sadlan, Salih bin Ghanim. (2000). Al-Qawa'id al-Fiqhiyyah al-Kubra wa ma Tafarra'a 'Anha. Riyad: Dar al-Balansiyah.

al-Syațibi, Abu Isḥaq bin Ibrahim. (2003). Al-Muwafaqat, (Jilid I). Beirut: Dar alKutub al-'Ilmiyah.

Al-Zair, Walid Salahuddin. (2010). Dhawabit al-Hajah al-Lati Tanzilu Manzilah al-Dharurah wa Tatbiqatuha 'ala al-Ijthad al-Mu'asirah. Majallah Jami'ah Dasakus li al-'Ulum al-Iqtișadiyyah wa al-2anuniyyah, (26)2.

As-Suyuthi, Abd ar-Rahman bin Abi Bakr. (1983). Al-Asybah wa al-Nazhair. Beirut: Dar al-Kutub Ilmiyyah.

As-Suyuthi, Jalaluddin Abdul Rahman bin Abi Bakr. (2006). Al-Asybah wa alNazhair, (Cet-II, Jilid-1). Cairo: Dar al-Salam.

Az-Djazuli. (2010). Kaidah-Kaidah Fikih. Jakarta: Kencana Prenada Media Group. Azzam, Abdul Aziz Muhammad. (2005). al-Qawa'id al-Fiqhiyah. Dar al-Hadis.

Az-Zuhaili, Wahbah. (1999). Konsep Darurat dalam Hukum Islam (Terjemahan). Jakarta: Gaya Media Pratama.

$\overline{\text { Al-Madãris, Volume 2 (1), } 2021}$ 
Beribadah Di Tengah Wabah Covid-19. (2020). Diakses 05 Juli 2020, dari https://aceh.tribunnews.com/2020/04/17/beribadah-di-tengah-wabahcovid-19.

Djazuli, Ahmad. (2000). Ushul Fiqh, Metodologi Hukum Islam, (Cet-1). Jakarta: RajaGrafindo Persada.

Haq, Abdul. (2005). Formulasi Nalar Fiqh, Telaah Kaidah Fiqh Konseptual. Surabaya: Khalista.

Menimbang Fatwa Kunci Mesjid. (2020). Diakses 05 Juli 2020, dari https://islamsantun.org/menimbang-fatwa-kunci-masjid-dan-tidak-shalatjumat.

Pembagian Zona Wilayah Penyebaran Corona. (2020). Diakses 02 Juli 2020, dari https://nasional.kontan.co.id/news/inilah-pembagian-zona-wilayahpenyebaran-corona-berdasarkan-risiko?page $=4$

Penularan Langsung dan tak Langsung Virus Corona. (2020). Diakses 02 Juli 2020, dari https://www.tagar.id/proses-penularan-langsung-dan-taklangsung-virus-corona,

Penyakit Corona Virus. (2020). Diakses 02 Juli 2020, dari https://www.klikdokter.com/penyakit/coronavirus,

Saenong, Faried F. (2020). FIKIH PANDEMI: Beribadah di Tengah Wabah. Jakarta Selatan.

Shaf Shalat Berjarak. (2020). Diakses 05 Juli 2020, dari https://republika.co.id/berita/q7f6rm366/shaf-sholat-berjarak-antisipasicorona-bagaimana-hukumnya.

Shalat Jumat Diera New Normal. (2020). Diakses 05 Juli 2020, dari https://nasional.kompas.com/read/2020/06/05/1229345l/shalat-jumat-diera-new-normal-dmi-ingatkan-protokol-pencegahan-COVID-19.

Syarifuddin, Amir. (2008). Ushul Fiqh, (Jilid II, cet. ke-4). Jakarta: Kencana Prenada Media Group.

Virus Corona. (2020). Diakses 02 Juli 2020, dari https://www.alodokter.com/virus-corona.

$\overline{\text { Al-Madãris, Volume 2 (1), } 2021}$ 